Agnieszka Zduniak

Uniwersytet Warmińsko-Mazurski w Olsztynie

\title{
Janusz Mariański, Nowa religijność i duchowość - mit czy rzeczywistość? Studium socjologiczne, Warszawskie Wydawnictwo Socjologiczne, Warszawa 2019, ss. 265
}

W ciągu ostatnich dziesięcioleci ogromną i wciąż rosnącą popularnością cieszy się pojęcie duchowości. Zjawiska określane tym mianem uchodziły niegdyś za część składową religii - jej pogłębiony, wewnętrzny wymiar, interesujący raczej teologów i duszpasterzy niż socjologów. Obecnie duchowość przeżywa swoją koniunkturę. Dzieje się tak przynajmniej z kilku powodów. W miarę zawężania się zakresu zjawisk określanych jako „religia”, które coraz częściej w społecznym odbiorze kojarzone są z kontekstem instytucjonalnym, rozszerza się zakres zjawisk niemających nic wspólnego z Kościołami, wyznaniami i denominacjami, a jednak odnoszących się do ludzkich poszukiwań wykraczających poza sferę rzeczywistości empirycznej, niekoniecznie powiązanych z sacrum teistycznym. Religia jest coraz częściej kojarzona z zestawem nieprzekraczalnych zakazów i nakazów, niepodlegających dyskusji dogmatów, z przymusem podejmowania decyzji i określania się raz na zawsze. Jest więc często postrzegana jako struktura opresyjna, a nie jest to cecha popularna w kulturze współczesnej, promującej wolność, samostanowienie, elastyczne dostosowywanie się do aktualnych wymogów i sytuacji. Duchowość natomiast z samej swej istoty zakłada wolność, brak ograniczeń w poszukiwaniach, możliwość ich ukierunkowania na to, co w danym momencie jest dla jednostki egzystencjalnie ważne i co może nawet w krótkim czasie się zmieniać, gdyż „duch wieje, kędy chce”. Pozytywne konotacje pojęcia duchowości i nie zawsze pozytywne skojarzenia związane z pojęciem religii znajdują odzwierciedlenie w warstwie leksykalnej. Badania pokazują, że coraz większy odsetek respondentów skłonny jest określać siebie mianem osób „uduchowionych, ale niereligijnych".

W dyskursie naukowym pojęcie duchowości ma już ugruntowaną pozycję, niekiedy zastępując lub wręcz wypierając pojęcie religii, nie oznacza to jednak, że desygnaty tego pojęcia składają się na zbiór wyraźnie zdefiniowany, odgraniczony od tego, co duchowością nie jest, i że istnieją jasne kryteria pozwalające na zaliczenie danego zjawiska do tego zbioru. Jest wręcz przeciwnie. Sfera duchowości jawi się jako coś w dużej mierze nieokreślonego, zbadanego jedynie cząstkowo, wybiórczo i często przy zastosowaniu nader arbitralnych kryteriów. Obecnie istniejąca literatura na ten temat to „terminologiczna i treściowa dżungla”. Zjawisko wymaga więc szczegółowej eksplikacji, systematyzacji, również ze względu na to, że nie dotyczy jedynie sfery interesującej socjologów religii, lecz wskazuje na dokonujące się obecnie ważne przemiany w życiu społecznym, będąc jednym z głównych trendów rozwojowych świata współczesnego. Nieuporządkowanie pojęć, trudności teoretyczne i metodologiczne w definiowaniu, rozmaicie interpretowane wyniki badań - wszystko to składa się na wyzwanie (a może nawet prowokację) dla ambitnych badaczy, którzy nie boją się wkraczania na niepewny grunt i badania zjawisk nowych, dopiero kształtujących się, w trakcie rozwoju, którego kierunek trudno określić i którego efekt końcowy jest zupełnie nieprzewidywalny.

Opracowania tak złożonego i niejednoznacznego obszaru zjawisk religijno-społecznych podjął się profesor Janusz Mariański, uznany i ceniony nie tylko w Polsce badacz życia religijnego. Książka pt. Nowa duchowość - mit czy rzeczywistość? Studium socjologiczne nie jest jednym z wielu przyczynków do socjologii duchowości, lecz bardzo udaną próbą całościowego opracowania niełatwej tematyki. Jest to - w pełnym tego słowa znaczeniu - kompendium wiedzy o duchowości i pracach poświęconych jej przez współczesnych socjologów i psychologów w Polsce i na świecie. Można zaryzykować twierdzenie, że każdy z badaczy, którzy interesują się duchowością, nawet tych, którzy poświęcili jej niejedno opracowanie, natrafi tu na informacje, z którymi jeszcze się nie zetknął. Autor przedstawia bowiem w swojej książce ogromną różnorodność koncepcji duchowości, prób jej zdefiniowania czy sklasyfikowania, uwzględniając nie tylko prace badaczy, których opracowania są już znane, lecz także co ciekawsze koncepcje młodszych autorów. Prezentuje również mało 
znane w Polsce badania dotyczące tego fenomenu w różnych krajach świata. Dzięki temu zjawisko duchowości jawi się w bardzo wartościowej odsłonie, mogącej zainteresować również tych, którzy do tej pory sytuowali ją raczej na marginesie swoich naukowych poszukiwań.

Opracowanie poświęcone jest duchowości religijnej oraz duchowości niereligijnej - fenomenowi autonomicznemu wobec zjawiska religijności. Dowiadujemy się, czym jest nowa duchowość, jakie są jej cechy charakterystyczne i jakie do tej pory poświęcono jej badania. Książka ma charakter opracowania teoretycznego zawierającego również odniesienia do badań empirycznych nad duchowością i nową duchowością. W rozdziale I przedstawiono religijność i duchowość w perspektywie psychologicznej i socjologicznej. Autor wspomina tu o zasadniczym z punktu widzenia socjologii religii problemie oddzielenia od siebie nowej duchowości oraz religijności. Choć religia jest zawsze związana z duchowością, to jednak nie każdy rodzaj duchowości wiąże się z religią, stąd liczne kontrowersje i dyskusje co do koncepcji nowej duchowości oraz metodologii jej badań. Rozdział ten przedstawia różne sposoby rozumienia i definiowania zjawiska duchowości i nowej duchowości w polskiej, niemieckojęzycznej oraz anglojęzycznej literaturze przedmiotu.

Rozdział II poświęcony jest duchowości religijnej i niereligijnej we współczesnych społeczeństwach. Badania nad tym zjawiskiem mają charakter interdyscyplinarny, zajmują się nimi m.in. biologia, filozofia, teologia, religioznawstwo, literaturoznawstwo, historia, antropologia, pedagogika, medycyna, psychologia i socjologia, z czego wynika wielość koncepcji i definicji. Na uwagę zasługuje konsekwentnie neutralne aksjologicznie podejście autora do omawianych zjawisk. Wbrew krytycznej postawie wielu socjologów oraz teologów potępiających nową duchowość jako rodzaj deficytu czy wręcz odejścia od Kościoła i religii, Janusz Mariański opowiada się zdecydowanie za postawą obiektywnego badacza, którego zadaniem jest diagnozowanie, interpretowanie i wyjaśnianie zjawisk, a nie ich wartościowanie w kategoriach „lepsze - gorsze”. Wzywa do większej empatii wobec współczesnych poszukiwań religijnych, do życzliwej neutralności i dostrzegania w nowej duchowości elementów pozytywnych, jak choćby tego, że może ona być przeciwwagą dla niekorzystnych tendencji rozwoju społecznego, takich jak pragmatyzm czy konsumpcjonizm. Zjawisko to jest faktem, którego nie można ignorować i które nie musi wcale stanowić konkurencji wobec tradycyjnych form religijności, może natomiast je rozwijać i dopełniać. Dlatego też, zdaniem autora, rozwój nowej duchowości stanowi symptom raczej desekularyzacji niż sekularyzacji.

W rozdziale III omówiono badania nad nową religijnością i duchowością we współczesnych społeczeństwach. Jest to obszerny przegląd materiału empirycznego pozyskanego dzięki badaniom prowadzonym w Stanach Zjednoczonych oraz krajach europejskich, takich jak Szwecja, Norwegia, Dania, Finlandia, Wielka Brytania, Belgia, Holandia, Portugalia czy Włochy. Pojawia się tu postulat badań skierowany również do socjologów polskich, którzy powinni poświęcać więcej uwagi nie tylko nowym formom duchowości chrześcijańskiej, lecz także szeroko rozumianej duchowości teistycznej i nieteistycznej, w tym również jej kontrowersyjnym z chrześcijańskiego punktu widzenia przejawom, takim jak duchowość sportu (np. pseudoreligijne przeżycia związane ze sportami ekstremalnymi), duchowość konsumpcji (galerie i centra handlowe jako „świątynie” konsumpcjonizmu i hedonizmu) itp. Autor zwraca uwagę na niedostatki tego typu badań w Polsce, co może być związane z wciąż bardzo silną tendencją kojarzenia pojęć, takich jak „religia”, „religijność” czy „duchowość” z religią chrześcijańską.

Zdaniem Janusza Mariańskiego osłabienie tradycyjnych form religijności nie oznacza zaniku religii, lecz jej dostosowanie do zmieniającego się kontekstu społeczno-kulturowego. Poszukiwanie sensu egzystencji jest stałą antropologiczną, dlatego nie sposób wyobrazić sobie społeczeństwa, w którym doszłoby do zaniku jakichkolwiek potrzeb religijnych czy duchowych. Socjologowie muszą nastawić się na badanie pojawiających się coraz to nowych pól religijności i duchowości, a także ich form społecznych niekiedy bardzo różniących się od potocznych wyobrażeń na temat religijności. Socjologia religii staje się dyscypliną wieloparadygmatyczną, której pole badawcze wciąż się poszerza. Współczesne przemiany w obrębie tego pola stanowią poważne wyzwanie również dla Kościołów, które powinny je uważnie obserwować i zwracać uwagę na pojawiające się w ich wyniku nowe oczekiwania i potrzeby tych, którzy nie chcą poprzestać na empiryczno-pragmatycznym wymiarze własnej egzystencji, lecz pragną nadać jej głębszy sens, przeczuwając, że świat taki, jaki jest, „nie jest jedyną możliwością człowieka”. 
Książka Janusza Mariańskiego stanowi niezwykle cenną pozycję, która nie ma odpowiednika na polskim rynku wydawniczym, skierowaną do wszystkich zainteresowanych współczesnymi zjawiskami religijnymi, ale przede wszystkim do badaczy, którzy chcieliby wypełnić istniejącą wciąż jeszcze w polskiej socjologii religii lukę w badaniach empirycznych dotyczących zjawiska nowej duchowości. Zawiera propozycje odpowiedzi na wiele ważnych pytań współczesnej socjologii duchowości, prowadzi przez gąszcz terminologii i koncepcji teoretycznych, wskazuje możliwe i ważne kierunki poszukiwań. Jednocześnie czyni to w sposób wyważony, nie narzucając gotowych rozwiązań, pobudzając do refleksji i poszukiwania nowych kierunków eksplorowania złożonego, ale bardzo interesującego zjawiska. Można się spodziewać, że po przeczytaniu tego opracowania wielu badaczy, którzy do tej pory traktowali zjawisko nowej duchowości jako mało znaczące, przekona się o potrzebie jego badania; wielu z tych, którzy do tej pory deprecjonowali je, zdobędzie się na większą ostrożność w formułowaniu sądów, a ci, którzy do tej pory nie interesowali się nim, będą mogli się przekonać, jak interesujący, a nawet fascynujący jest to obszar. Bo oprócz tego, że książka stanowi sumienne i rzetelne opracowanie naukowe, jest też - po prostu - ciekawa i niezwykle inspirująca. Nie ulega wątpliwości, że przyczyni się do zdynamizowania polskich badań socjologicznych nad nową duchowością. 